\title{
ISLAM, RADIKALISME DAN DERADIKALISASI BERBASIS PANCASILA
}

\author{
Syaiful Arif \\ Peneliti Perhimpunan Pendidikan Demokrasi (P2D)
}

\begin{abstract}
ABSTRAK: Radikalisme agama (Islam) yang mengembangkan paham teologis kontra-Pancasila dan Negara Kesatuan Republik Indonesia (NKRI) bisa dilawan dan dilunakkan dengan Pancasila itu sendiri. Hal ini disebabkan oleh fakta bahwa penyebab radikalisme tersebut ialah kesalahpahaman terhadap Pancasila beserta sistem politik yang dinaunginya. Pancasila dianggap sebagai ideologi politik sekular, padahal ia justru merawat pola hubungan agama dan negara yang menegakkan nilainilai ketuhanan di satu sisi, serta kebaikan publik di sisi lain. Deradikalisasi agama berbasis Pancasila oleh karenanya menerapkan dua strategi. Pertama, pembuktian dimensi agama dari Pancasila dan NKRI untuk meruntuhkan penilaian sekularistik yang dilakukan kaum radikal. Kedua, pembelajaran hakikat politik yang termuat di dalam Pancasila. Hakikat politik ini yang sebenarnya lebih sesuai dengan cita-cita politik Islam, daripada ideologi Islamisme yang penuh kekerasan.
\end{abstract}

KATA KUNCI: Islam, radikalisme, deradikalisasi, Pancasila.

ABSTRACT: Religious radicalism (Islam) developed the theological thought to counter-Pancasila and the Republic of Indonesia (NKRI), it can be fought and softened with Pancasila itself. This is due to the fact that the cause of such radicalism is a misunderstanding to the Pancasila and its political system. Pancasila is regarded as a secular political ideology, whereas it actually cared pattern for the relationship between religion and state that upholds the values of divinity on the one side, and the public virtue on the other side. Deradicalization of religion based on Pancasila can be applied with two strategies. First, proving the 
existence of religious dimension of Pancasila and Republic of Indonesia to undermine the secular claims from the radical groups. Second, learning the nature of politics which contained in Pancasila. These nature of politics are more in line with the political ideals of Islam, rather than the ideology of Islamism which tends to the violent.

KEYWORDS: Islam, radicalism, deradicalization, Pancasila.

\section{Pendahuluan}

Tulisan ini berangkat dari asumsi dasar bahwa radikalisme agama yang berkembang di Indonesia bisa dilunakkan melalui pendidikan Pancasila untuk umat beragama. Hal ini terjadi karena radikalisme tersebut telah melakukan deligitimasi Pancasila sebagai dasar negara dan bangunan normatif kehidupan berbangsa. Maka dengan menggunakan Pancasila sebagai basis bagi deradikalisasi agama, radikalisme agama secara otomatis dihancurkan sekaligus dilunakkan.

Dalam kaitan ini, yang dimaksud sebagai radikalisme agama ${ }^{1}$ di tulisan ini ialah radikalisme yang berkembang di kalangan Muslim, karena dua hal. Pertama, terkait keterbatasan penulis untuk berbicara di luar tradisi Islam. Kedua, karena secara faktual, radikalisme agama yang berkembang di Indonesia memang berbasis doktrin Islam. Perkembangan ini terjadi sejak di ranah pemikiran, kultur, gerakan sosial hingga aksi terorisme. Maka fokus kepada radikalisme Islam menjadi hal yang patut dilakukan dalam rangka

\footnotetext{
1 Dalam hal ini, penulis fokus pada penggunaan istilah radikalisme daripada fundamentalisme. Mengapa? Karena keduanya memiliki makna yang identik. Fundamentalisme artinya gerakan keagamaan yang berbasis pada penafsiran literal atas fundamen agama, yakni kitab suci. Sedangkan radikalisme merupakan paham keagamaan yang menjadikan agama sebagai ideologi politik, dan oleh karenanya menghendaki perubahan masyarakat secara radikal. Karena makalah ini terkait dengan proses deradikalisasi, maka penulis lebih menggunakan istilah radikalisme tersebut. Untuk mengetahui ragam istilah gerakan Islam radikal, baca Syaiful Arif, Deradikalisasi Islam, Paradigma dan Strategi Islam Kultural (Depok: Koekoesan, 2010).
} 
mengembangkan deradikalisasi agama.

Sebagaimana diketahui, kehidupan kebangsaan kita telah diwarnai oleh radikalisme agama, terutama yang berkembang di kalangan Islam. Hal ini tidak terjadi di masa Orde Baru karena varian radikal ini dibungkam melalui "kedamaian yang mencemaskan". Ekstrim kanan agama disamakan bahayanya dengan ekstrim kiri Komunis. Paska runtuhnya Orde Baru, kekuatan politik Islam, baik radikal maupun formalis (partai Islam) bangkit, menghadirkan wajah agama yang sering tak ramah dengan kehidupan publik.

Secara umum radikalisme ini bisa merupakan gerakan trans-nasional yang hadir di Indonesia sejak dekade 1980 dalam bentuk gerakan tarbiyah. ${ }^{2}$ Di sisi lain ia merupakan kesinambungan gerakan Islam baik yang bersifat ekstrim seperti Darul Islam/Tentara Islam Indonesia (DI/TII) maupun formalis-institusional dalam bentuk partai-partai Islam pengusung Piagam Jakarta.

Yang termasuk dalam Islam trans-nasional merujuk pada pola keislaman salafi. Sebuah pola keislaman yang hendak memurnikan Islam (purifikasi) dari segenap hal di luar Islam, menuju praktik kesalehan kaum pendahulu (salaf al-shalihin). Yang dimaksud kaum pendahulu (salaf) ialah sahabat Nabi Muhammad SAW, tabi'in (pengikut sahabat) dan tabi'ittabi'in (pengikut dari pengikut sahabat). Praktik ini mewakili zaman keemasan Islam di mana (konon) berdiri Negara Madinah dengan sistem politik khilafah Islamiyyah, serta praktik keagamaan berbasis dua sumber utama: alQur'an dan hadist. Tidak ada budaya lokal, filsafat, tasawuf hingga nasionalisme beserta sistem politik demokrasi yang dianggap menodai serta

\footnotetext{
2 Tarbiyah artinya pendidikan. Gerakan Islam tarbiyah merupakan gerakan Islam radikal yang menggunakan strategi pendidikan. Hanya saja pendidikan yang dimaksud bukan melalui pendirian lembaga pendidikan, melainkan melalui pengkaderan dalam bentuk pengkajian Islam secara melingkar (halaqoh) di beranda masjid. Sebagai strategi gerakan, tarbiyah dibedakan dengan gerakan politik melalui parlemen dan gerakan teroristik secara militer.
} 
meruntuhkan kejayaan Islam.

Di dalam tulisan ini, fokus pembahasan tertuju pada radikalisme Islam politik yang mengembangkan ideologi kontra-Pancasila dan Negara Kesatuan Republik Indonesia (NKRI). Mengapa? karena radikalisme jenis ini, yang berbeda secara definitif dengan radikalisme budaya (puritanisme) dan teroristik, menjadi poros yang menggerakkan semua model radikalisme Islam. Ini terjadi karena varian ini menjadi produsen gagasan dan ideologi Negara Islam yang menjadi pijakan dan tujuan dari sebagian besar gerakan radikal Islam. Fokus pada radikalisme Islam politik juga terkait dengan tawaran Pancasila sebagai basis deradikalisasi, karena kaum radikal tersebut memang menempatkan Pancasila sebagai ideologi politik yang dimusuhi.

\section{Jenis Radikalisme Islam}

Kaum radikal Islam memiliki karakter sama dalam hal penolakan terhadap sistem sosial-politik modern, dan perjuangannya untuk mengembalikan kejayaan Islam yang dinilai runtuh akibat modernitas. Abdurrahman Wahid dalam Islamic Fundamentalism, A Shouteast Asia Perspectivedengan bagus menggambarkan karakter ini:

"Another factor behind the emergence of Islamic fundamentalism is the inability of many Muslims in the region to integrate their pecuilar systems of education, family structure, economic enterprises and even political aspirations into the mainstream of each nation. The disappointment and dissaticfaction that follow their failure to integrate themselves into the mainstream puts them at a loss, which they see as due to the lack of spiritual dimension of their lives. Accordingly, Islamic fundamentalism becomes an tractive 'escape way' to regain in an inner way what they lose in the outer one.

A mere re-assertion of Islamic theachings in the face of the modernization onslaughts does not warrant a cry of wolf againts the alleged 'Islamic fundamentalism'. But the fact that the majority of those Muslims.. Which are really fundamentalistic in outlook and attitude. Those groups reject the validity of the current national government, the validity of the orthodoxy of 
Islamis establishments, the validity of the national idoelogy, and of course the validity of the Muslim Majority's participation in national politics". ${ }^{3}$

Dalam kutipan di atas dijelaskan bahwa kemunculan fundamentalisme atau radikalisme Islam diawali oleh ketidakmampuan sebagian Muslim dalam mengintegrasikan sistem pendidikan, struktur keluarga, usaha ekonomi dan aspirasi politik Islam ke dalam kehidupan berbangsa modern. Ketidaksetujuan dan ketidakpuasan yang disebabkan oleh kegagalan mereka dalam mengintegrasikan diri ini menempatkan mereka sebagai pihak yang kalah, yang mereka pahami sebagai hilangnya dimensi spiritual dalam kehidupan mereka. Oleh karenanya, sikap fundamentalis atau radikal menjadi jalan pelarian (escape way) untuk mendapatkan kembali "dengan cara dalam" (in an inner way) atas kekalahan yang dialami pada "sisi luar" (the outer one).

Artinya, kaum fundamentalis atau radikal adalah orang-orang yang menolak sistem kehidupan berbangsa modern karena dianggap tidak sesuai dengan nilai-nilai Islam. Ini disebabkan oleh ketidakmampuan mereka dalam mengintegrasikan nilai, ajaran dan konsep Islam ke dalam struktur masyarakat modern, baik pada ranah pendidikan, keluarga, ekonomi hingga politik. Ketidakmampuan ini menempatkan mereka sebagai orang-orang yang kalah, melalui anggapan "Islam dalam ancaman", sehingga mereka menolak sistem sosial modern untuk menegakkan idealitas Islam. Sayangnya, upaya menegakkan kembali kejayaan Islam ini dilakukan dengan "cara dalam", yakni cara-cara keagamaan, atas kekalahan pada ranah sosial-politik. Cara-cara keagamaan ini bisa dilihat dalam perjuangan menegakkan khilafah untuk mengganti demokrasi.

Akan tetapi, peneguhan kembali nilai-nilai Islam untuk menghadapi modernisasi tidak secara otomatis merupakan bagian dari fundamentalisme

\footnotetext{
3 Abdurrahman Wahid, Islamic Fundamentalism, A Shouteast Asia Perspective (sumber tak terlacak, 1981), 4.
} 
atau radikalisme Islam. Sebab sebuah gerakan Islam bersifat fundamentalistik atau radikal jika mengembangkan tiga sikap:

- Menolak pemerintahan nasional

- Menolak paham keislaman mainstream (ortodoks) di sebuah negeri

- Menolak ideologi politik nasional

- Menolak partisipasi politik mayoritas Muslim dalam sistem demokrasi

Artinya, hanya ketika sebuah gerakan Islam menolak pemerintahan dan negara nasional, ideologi politik nasional, partisipasi mayoritas Muslim dalam demokrasi, serta mazhab keislaman mainstream di suatu negeri. Baru ia masuk dalam kategori fundamentalis atau radikal. Dalam kategori ini, sebuah gerakan radikal mengembangkan ancaman yang bersifat nasional, baik secara politik maupun keamanan.

Dari paparan ini bisa dipahami bahwa Wahid telah memberikan dua macam gambaran tentang radikalisme Islam. Pertama, ia menggambarkan karakter umum dari kondisi psiko-keagamaan kaum radikal yang menolak kehidupan modern karena merasakan keterancaman religius akibat hegemoni modernitas. Kedua, ia memberikan batasan spesifik tentang pola dan sikap fundamentalistik di dalam kehidupan politik dengan menunjukkan penolakan kaum radikal atas sistem politik nasional sebuah bangsa. Jika tidak melakukan penolakan tersebut, sebuah gerakan Islam belum masuk kategori fundamentalis atau radikal.

Pembatasan Wahid di atas sebenarnya menandai keragaman di dalam tubuh gerakan radikal Islam yang secara struktural membentuk sebuah piramida radikalisme, sebagaimana tergambar di dalam bagan berikut: 


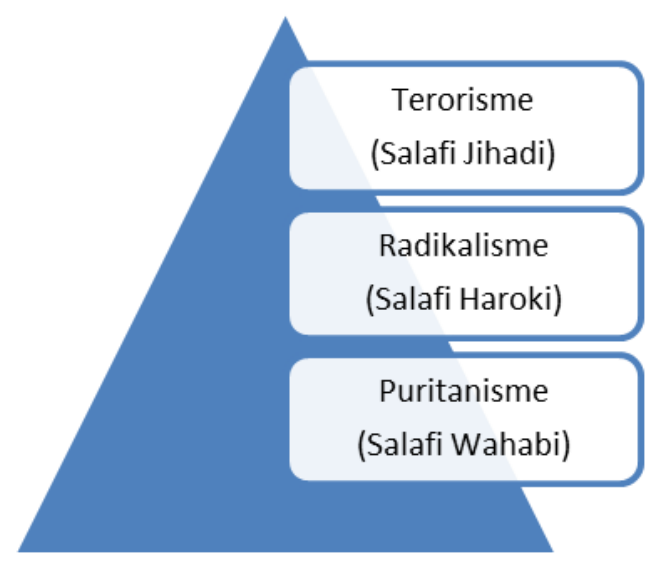

Pada level terbawah, radikalisme Islam didasari oleh sikap beragama puritan: memurnikan agama dari produk dan praktik kebudayaan. Sikap ini lahir dari pembenturan antara agama dan budaya, sebab agama dianggap murni aturan Tuhan yang tidak boleh dinodai oleh budaya. Sebagai sikap dasar, puritanisme merupakan sifat umum dari semua corak radikalisme Islam, meskipun gerakan puritan spesifik, yakni kaum salafi Wahabi tidak berpolitik sebagaimana salafiharoki (pergerakan) dan tak selalu menganjurkan terorisme seperti salafijihadi.

Di atas puritanisme agama terdapat radikalisme, yang digerakkan oleh kaum salafiharoki. Disebut radikal karena ia ingin menciptakan perubahan masyarakat secara menyeluruh berbasis ideologi Islam, melalui gerakan sosial (haroki). Ujung dari perjuangan radikalisme ialah penggantian sistem politik modern dengan sistem politik Islam, baik dalam bentuk khilafah Islamiyyah global maupun daulah Islamiyyah berskala nasional. ${ }^{4}$ Yang

4 Negara Islam nasional (daulah Islamiyyah) merupakan pelunakan realistis dari sebagian
besar aktivis Islam atas cita-cita penegakan sistem politik Islam, setelah kemustahilan pendirian
khilafah Islamiyyah secara global pasca runtuhnya Khilafah Turki Ustmani pada 1924. Selain
lingkup kekuasaan yang berbeda di antara keduanya, struktur kenegaraan pun agak berbeda.
Daulah Islamiyyah karena mengadopsi nation-state, ia mengadopsi trias politica (eksekutif,
legislatif, yudikatif) berbasis demokrasi. Hanya saja pengadopsian ini dilakukan secara implisit 
dimaksud dengan radikalisme Islam di dalam tulisan ini terutama merujuk pada gerakan salafiHaroki yang berpolitik, yang merupakan varian Islamisme terdidik dari kelas menengah kaum Islamis. Selain berpolitik, kaum radikal bersifat puritan seperti salafi Wahabi meski tak selalu terlibat dalam terorisme.

Sedangkan puncak dari radikalisme Islam ialah terorisme yang menggunakan pendekatan militer demi penegakan khilafah untuk meruntuhkan hegemoni Barat (AS dan Israel). Ia lahir dari medan perang Afghanistan melawan Uni Soviet pada 1979, dan semakin mengental paska pengeboman gedung WTC AS pada 2001. Salafi jihadi adalah kaum radikal yang menggerakkan jihad bermakna perang melawan pemerintahan Barat dan pemerintahan Muslim yang tidak mendirikan negara Islam. Pandangan budayanya puritan, karena sebagian kaum jihadi juga merupakan kaum Wahabi, serta ingin mendirikan sistem politik Islam sebagaimana salafi haroki.

Jika dirinci lebih lanjut, ketiga jenis radikalisme Islam di atas bisa dijelaskan sebagai berikut; Pertama, salafi puritan. Ini digerakkan oleh Wahabisme, sebuah sekte Islam di Saudi Arabia pengikut Muhammad bin Abdul Wahab (1701-1793 M) yang menganjurkan pemurnian agama dari

\footnotetext{
dengan mendasarkan diri pada tradisi politik Islam. Misalnya, lembaga legislatif yang disamakan dengan Majelis Syuro berisi ahlul halli wal 'aqdi (ahwa): ahli analisis dan memutuskan, beranggota para elit berpengaruh di masyarakat. Eksekutif dijabat sultan atau khalifah yang dipilih secara demokratik oleh ahwa, serta yudikatif yang dipimpin oleh qadli (ahli hukum Islam). Perbedaan mendasar antara daulah Islamiyyah dengan negara-bangsa terletak pada basis konstitusionalnya: daulah Islamiyyah berbasis syariah, sedang negara-bangsa berbasis hukum positif berlatar hukum kodrat. Tugas utama daulah ialah penerapan syariah, sedangkan negara-bangsa mewujudkan kedaulatan rakyat berbasis demokrasi. Oleh karenanya, meskipun meniru bentuk negara nasional, daulah Islamiyyah tak selaras dengan cita-cita politik kebangsaan yang plural. Sementara itu khilafah yang bersifat global memberi kekuatan penuh pada khalifah secara totaliter. Lihat Anthony Black, The History of Islamic Political Thought: From the Prophet to the Present (Edinburgh: Edinburgh University Press, 2011), 14. Lihat juga Jacques Waardenburg, Islam, Historical, Social and Political Perspective (New York: Walter de Gruyter, 2002), 35 .
} 
budaya lokal. Artinya, wilayah gerakan ini berada pada ranah kultural dengan metode gerakan dakwah, amar ma'ruf nahy munkar. Tidak ada tujuan politik apalagi terorisme di dalam gerakan ini. Akan tetapi sebagai embrio dasar bagi radikalisme, para pengikut Wahabi bisa dan telah mengembangkan aktivisme perang, sebagaimana terjadi pada perang Afghanistan (1979).

Di Indonesia, Wahabisme disebarkan bersamaan dengan pendirian Lembaga Ilmu Pengetahuan Islam dan Arab (LIPIA) yang didirikan pada tahun 1980. Perguruan tinggi ini merupakan cabang dari Universitas Imam Muhammad ibn Saud, Riyadl. Beberapa alumni yang tercatat menjadi tokoh salafi di Indonesia ialah; Yazid bin Abdul Qadir Jawas (Pesantren Minhajus Sunnah, Bogor), Farid Okbah (Direktur al-Irsyad), hingga Anis Matta (Presiden Partai Keadilan Sejahtera).

Kedua, salafi politik yang menghendaki pendirian Negara Islam baik dalam bentuk Negara Islam Nasional seperti dikehendaki Ikhwanul Muslimin (IM) maupun kekhilafahan global seperti diperjuangkan Hizbut Tahrir (HT). Di Indonesia, IM Tarbiyah mendirikan Partai Keadilan (PK) yang berubah menjadi Partai Keadilan Sejahtera (PKS). Partai ikhwan ini telah melakukan pelunakan ideologi, dari pengusungan Piagam Jakarta demi penerapan syariat, kepada Piagam Madinah yang disamakan dengan Pancasila. Sementara itu Hizbut Tahrir Indonesia (HTI) telah menapaki tahap kedua perjuangan, yakni tafa'ul ma'al ummah (sosialisasi kepada umat) melalui konferensi khilafah, yang pada tahun 2007 melayangkan Surat Terbuka kepada Presiden Soesilo Bambang Yudhoyono (SBY) untuk mendirikan khilafah Islamiyah di Indonesia. $^{5}$ Pada titik ini, jika IM

\footnotetext{
5 HTI mengembangkan tiga tahapan perjuangan. Pertama, marhalah tasqif (tahapan pengkaderan) yang dilakukan sejak 1980 melalui kajian halaqoh di kalangan mahasiswa di kota-kota besar. Kedua, marhalah tafa'ul ma'al ummah (tahapan sosialisasi masyarakat) melalui Konferensi Khilafah Internasional yang dilakukan pada 2001, sekaligus deklarasi pendirian HTI. Ketiga, marhalah istilam al-hukmi (tahapan pendirian pemerintahan), yakni pendirian
} 
menggunakan jalur parlemen dan terlibat dalam demokrasi. Maka HT dan HTI memilih jalur ekstra-parlementer melalui propaganda anti-nasionalisme dan demokrasi.

Ketiga, salafi jihadi yang menjadikan terorisme sebagai strategi, baik bagi penegakan khilafah maupun perlawanan militer terhadap AS dan Israel.

Pada titik inilah ancaman nyata radikalisme terletak pada salafi jihadi. Umumnya mereka adalah eks-mujahidin yang terlibat dalam perang di Timur-Tengah baik perang Afghanistan (1979), perang Arab-Israel, maupun intervensi AS terhadap politik di Irak, dll. Al-Qaeda misalnya, pada awalnya merupakan bentukan AS untuk melawan Uni Soviet pada perang Afghanistan. Namun belakangan, pimpinannya, Osama bin Laden berbalik arah melawan AS terutama setelah "perang global melawan terorisme" paska pengeboman gedung WTC 11 September 2001. Demikian pula organisasi teroris baru, Islamic State of Iraq and Syiria (ISIS), yang awalnya merupakan Al-Qaeda fi Iraq. Gerakan ini di-back up oleh AS untuk menghambat pengaruh Iran di Irak paska lengsernya Saddam Husein.

Embrio gerakan ini tentulah Ikhwanul Muslimin Quthbian. Yakni Ikhwan yang telah bergeser dari gerakan tarbiyah melawan peradaban Barat melalui gerakan pendidikan. Gerakan Ikhwan ini bersumber pada ajaran Hassan al-Banna, menuju Ikhwanul Muslimin Jihadis berbasis ajaran Sayyid Quthb yang menekankan jihad (perang) sebagai metode perlawanan atas Barat. $^{6}$

khilafah Islamiyyah. Di Indonesia, HTI hanya akan mencapai tahapan kedua, dan tidak akan meraih tahapan ketiga, karena sifat dasar gerakannya yang ekstra-parlementer, ditambah kuatnya kekuatan TNI-Polri. Lihat Ainur Rafiq al-Amin, Membongkar Proyek Khilafah ala Hizbut Tahrir Indonesia (Yogyakarta: LKiS, 2012) dan Imdadun Rohmat, Arus Baru Islam Radikal, Transmisi Revivalisme Islam Timur Tengah ke Indonesia (Jakarta: Penerbit Airlangga, 2005).

6 Michael Bonner, Jihad in Islamic History, Doctrines and Practice (New Jersey: Princeton University Press, 2006), 92. 
Doktrin permusuhan atas pihak-pihak yang tidak menerapkan syariat ini didasarkan pada surat al-Maidah ayat 44: "Barangsiapa tidak memutuskan menurut apa yang diturunkan Allah, maka mereka itu adalah orang-orang kafir". Sehingga, "Dan perangilah kaum musyrikin itu semuanya sebagaimana mereka memerangi kamu semuanya" (al-Taubah:36). Demikian pula surat al-Anfal ayat 39: "Perangilah mereka (orang-orang kafir) sehingga tidak ada lagi fitnah. Agama seluruhnya adalah milik Allah".

Pemahaman inilah yang melahirkan pandangan takfiri (pengafiran) yang merupakan doktrin utama dari kaum jihadi, sebagaimana diamini oleh Najih Ibrahim Abdullah, mantan tokoh Jamaah Islamiyah (JI) Mesir. Doktrin takfiri ini awalnya dikembangkan oleh Sayyid Quthb dan dipraksiskan oleh orgamisasi jihadis Mesir seperti Jamaah al-Muslimin pimpinan Ali Abduh Ismail dan Syukri Mustofa, Jamaah Jihad atau Tanzimul Jihad pimpinan Nabil al-Bar'i, Jamaah Islamiyah (1973) pimpinan Umar Abdurrahman, AlJabhah li Tahrir al-Islam (1974) pimpinan Salih Abdullah al-Suriah, hingga Al-Qaeda dan kini, Islamic State of Iraq and Syiria(ISIS). Dalam konteks ini para mujahid telah meluaskan definisi kafir kepada pihak-pihak:

- Pemerintahan yang tidak menjadikan al-Qur'an dan hadist sebagai konstitusi (qanun) dan syariat sebagai undang-undang (dustur).

- Mereka yang membantu orang yang dinilai kafir dan rezimnya.

- Mereka yang meninggal karena mempertahankan pemerintahan yang dinilai kafir.

- Mereka yang berpartisipasi dalam partai non-Islam.

- Mereka yang memilih kandidat anggota parlemen bukan dari partai Islam.

- Mereka yang menaati negara yang dinilai kafir.

- Mereka yang menghormati bendera, lagu nasional dan hormat kepada pasukan 
Pandangan takfiri yang meluaskan definisi kafir dari teologi ke politik ini kemudian disempurnakan melalui pemaknaan jihad sebagai perang (qital) sebagaimana dirumuskan oleh Abdullah Azam. ${ }^{7}$

Dalam hal ini, Azam kemudian menempatkan ayat jihad sebagai perang dalam Surat al-Taubah, sebagai ayat yang mengganti (nashih manshuh) ayat-ayat jihad dalam artian damai sebagaimana terdapat dalam alNahl: 125 dan al-Hujurat:15. Pandangan Azam inilah yang menjadi pedoman para mujahidin, yang dikhotbahkan selama perang Afghanistan dan disebarluaskan oleh para alumni mujahidin di Asia Tengah, Chechnya dan Bosnia. Ajaran Azam pula yang menjadi menu wajib pengajaran di kampkamp pelatihan mujahidin di Mindanao, Filipina dan Poso, Indonesia. ${ }^{8}$

Berangkat dari sinilah radikalisme jihadi berkembang di Indonesia. Jalurnya melalui al-Jama'ah al-Islamiyah (JI) Asia Tenggara yang awalnya dipimpin oleh Abdullah Sungkar, dan kemudian diganti oleh Abu Bakar Ba'asyir. Aksi Bom Bali I dan II disinyalir dilakukan para aktivis JI, yakni Amrozi CS. Alasannya jelas: Indonesia ialah negeri kafir karena tidak menjadikan syariah sebagai konstitusi, sehingga wilayahnya masuk dalam kategori daerah perang (dar al-harb). Karena wilayah perang, maka halal menjadi objek teror. Apalagi Bali merupakan pusat turisme di mana para turis (bule) diidentikkan dengan orang-orang kafir. ${ }^{9}$

Perjalanan JI tidak mulus, sebab Ba'asyir kemudian memisahkan diri dan membentuk Majelis Mujahidin Indonesia (MMI). Karena konflik internal, Ba'asyir kemudian mendirikan organisasi lagi, yakni Jamaah Ansharut Tauhid (JAT). Ketika ISIS didirikan dan pimpinannya, Abu Bakr

\footnotetext{
7 Asma Afsaruddin, Striving in the Path of God, Jihad and Martyrdom in Islamic Thought (New York: Oxford University Press, 2013), 205.

8 As'ad Said Ali, Al-Qaeda, Tinjauan Sosial-Politik, Ideologi dan Sepak Terjangnya (Jakarta: LP3ES, 2014), 15-47.

9 Mike Millard, Jihad in Paradise, Islam and Politics in Southeast Asia (London: An East Gate Book, 2004), 69.
} 
al-Baghdadi mendeklarasikan diri sebagai khalifah, Ba'asyir membaiatnya (menerima) dan akhirnya membentuk Jamaah Ansharul Khilafah (JAK). Dengan demikian, paska ditangkapnya para aktivis JI, ISIS menjadi primadona terorisme bagi kalangan jihadi setelah pimpinan Al-Qaeda, Osama bin Laden dibunuh tentara AS. Artinya ke depan ISIS akan menjadi "payung besar" yang menyemangati para aktivis jihadi, karena gerakan ini telah berhasil menduduki perbatasan Irak dan Syiria dan mendirikan apa yang mereka klaim sebagai Negara Islam. ${ }^{10}$

Di tengah tiga varian radikalisme salafi di atas, proses deradikalisasi berbasis Pancasila terfokus pada varian salafi haroki yang mengembangkan delegitimasi atas NKRI demi penegakan sistem politik Islam. Mengapa salafi haroki? Karena varian teroristik jihadi membasiskan pemikirannya pada pemikiran politik salafi haroki. Dengan demikian, deradikalisasi berbasis Pancasila mengarah pada deideologisasi pemikiran politik kaum radikal Islam sehingga bisa menerima Pancasila dan NKRI sebagai pandangan hidup dan aturan kehidupan bersama dalam masyarakat Indonesia.

\section{Agama dan Pancasila}

Untuk mengembangkan proses deradikalisasi berbasis nilai-nilai Pancasila, diperlukan pemahaman akan hubungan agama dan negara dalam terang Pancasila. Sebab penolakan kaum beragama terhadap dasar negara

\footnotetext{
10 Sikap kaum Islam radikal terhadap ISIS tidak menyatu, sebagian masih enggan bergabung, sebagian mendukung termasuk Abu Bakar Ba'asyir. Kemajuan militer ISIS akan menjadi faktor penarik dukungan. Pendukung ISIS antara lain JAT, JTW, MIT, Al Muhajirun, ex NII. Pembentukan ISIS di Indonesia diumumkan oleh murid Aman Abdurrahman, yakni Marwan alias Abu Musa. ISIS juga telah mengizinkan terbentuknya perwakilan Indonesia yang disebut Majmu'ah al-Arkhobili di bawah pimpinan Bahrum Shah (asal Bandung) dan wakilnya Asyikin Nur (Malaysia). Namun ISIS belum mengizinkan perwakilan militer atau Katibah untuk Asia Tenggara (masih berada di tangan jaringan ISIS Asia Tengah). Perkembangan ISIS di Indonesia saat ini masih tahap pembinaan melalui kaderisasi (tarbiyah) dan penataan organisasi. Sejauh ini belum terbentuk Qoidah Aminah yang merupakan penggemblengan militer. Dikutip dari As'ad Said Ali, 2016.
} 
ini, disebabkan oleh kesalahpahaman atas pola hubungan ini.

Secara normatif dan ideologis, hubungan antara agama (Islam) dan negara di Indonesia telah diharmoniskan oleh dasar negara Republik Indonesia, yakni Pancasila. Dikatakan harmonis karena dasar negara ini telah mengakomodir dua kutub ideologi yang bertentangan, yakni nasionalisme sekular dan nasionalisme Islam, dengan membentuk suatu negara berketuhanan. Hal ini bisa terjadi karena sila pertama Pancasila ialah Ketuhanan Yang Maha Esa.

Sebagaimana ditegaskan oleh Panitia Persiapan Kemerdekaan Indonesia yang berunding pada 17 Juli 1945, sila ketuhanan yang diletakkan di urutan pertama Pancasila, memiliki makna signifikan dalam konteks hubungan agama dan negara. Makna ini merujuk pada sifat semua sila di bawahnya, yakni Kemanusiaan yang Adil dan Beradab, Persatuan Indonesia, Kerakyatan yang Dipimpin oleh Hikmat Kebijaksanaan dalam Permusyawaratan/Perwakilan, serta Keadilan Sosial Bagi Seluruh Rakyat Indonesia; yang bersifat ketuhanan. Artinya, semua prinsip kemanusiaan, persatuan (nasionalisme), kerakyatan (demokrasi) dan keadilan sosial itu merupakan pengamalan dari nilai-nilai ketuhanan. Inilah mengapa Pancasila telah menyelamatkan Indonesia untuk tidak menjadi negara sekular. Kekhawatiran kaum nasionalis Islam tak terjadi. ${ }^{11}$

Pada saat bersamaan, dengan memilih kata "ketuhanan" sebagai ganti kata "Allah" dan "Tuhan", telah menjadikan nilai ketuhanan Pancasila sebagai nilai religius umum yang dimiliki oleh semua agama, termasuk aliran kepercayaan. Apalagi dengan dihapusnya "tujuh kata" Piagam Jakarta 1945, yang berbunyi, "dengan kewajiban menjalankan syariat Islam bagi pemeluk-pemeluknya", telah menjadikan Indonesia bukan hanya milik umat Islam. Ini yang membuat Pancasila tidak menempatkan NKRI sebagai

\footnotetext{
11 Eka Darmaputera, Pancasila, Identitas dan Modernitas (Jakarta: PT BPK Gunung Mulia, 1997),
} 108. 
negara agama, atau Negara Islam, selayak kekhawatiran kaum nasionalis sekular.

Dari sini Pancasila kemudian membentuk sebuah negara "jalan tengah": bukan negara agama dan bukan negara sekular. Ini tentu melampaui hubungan integratif agama dan negara yang membentuk negara agama, juga pola separatif yang memisahkan agama dari negara. Melampaui itu, ia telah membentuk suatu "teo-demokrasi", dalam arti, kedaulatan Tuhan dibaca dalam satu tarikan napas dengan kedaulatan rakyat.

Dalam kaitan ini, Pancasila telah menggariskan prinsip hubungan agama dan negara yang strategis baik dari sudut pandang negara maupun agama. Prinsip hubungan ini, oleh Alfred Stephan disebut sebagai toleransi kembar (twin toleration) di mana negara menoleransi agama dengan tidak bertindak interventif atas pengamalannya, namun tetap melindungi dan menfasilitasi kehidupan beragama di kalangan umat. Demikian pula agama menoleransi negara dengan tidak memaksakan nilainya, menjadi agama negara, namun pada saat bersamaan menopang kehidupan bernegara melalui pembentukan etika politik di tengah kehidupan kewarganegaraan. ${ }^{12}$

Dalam toleransi negara atas agama, terdapat beberapa prinsip. Pertama, negara menghormati agama sebagai nilai yang memiliki ruang tersendiri, yang berada di wilayah transendental manusia dan kehidupan sosio-kultural. Oleh karenanya negara tidak mengintervensi agama, justru sebaliknya, menjamin dan melindungi kebebasan beragama yang menjadi bagian dari kebebasan sipil (civil liberty) warga negara. Penghormatan dan jaminan ini termaktub pada Pasal 29A UUD 1945. Lebih jauh lagi negara tidak membatasi jumlah agama dan oleh karenanya tidak dalam kapasitas

\footnotetext{
12 Alfred Stepan, Religion, Democracy and the 'Twin Tolerations' dalam L. Diamond, M. F. Plattner. dan P.J. Costopoulos (eds), World Religions and Democracy (Baltimore: The Johns Hopkins University Press, 2005), 5-6.
} 
mengakui atau melarang berkembangnya suatu agama, sebagaimana ditegaskan oleh UU No. 1 PNPS Tahun 1965. Meskipun terdapat penyebutan enam agama; Islam, Kristen, Katolik, Hindu, Buddha dan Konghucu, namun penyebutan ini merujuk pada fakta sosiologis agama yang dipeluk mayoritas warga negara, tanpa mengekslusi agama di luar enam agama tersebut. Ini membuktikan bahwa Indonesia merupakan negara netral agama, sehingga ia menaungi semua umat beragama.

Kedua, otonomi negara dari agama ini dibarengi dengan kebijakan menfasilitasi kehidupan beragama di kalangan umat, baik melalui pembuatan regulasi, pengesahan penerapan hukum agama, hingga mediasi kerukunan umat beragama. Pembentukan Kementerian Agama merupakan fasilitasi ini, di mana di dalamnya terdapat regulasi kehidupan beragama, pemberian bantuan kegiatan dan pendidikan agama, hingga pembentukan Forum Kerukunan Umat Beragama (FKUB). Ini menunjukkan komitmen negara dalam membantu kelangsungan kehidupan beragama tanpa melakukan intervensi atas praktik keagamaan. Fungsi negara dalam konteks ini lebih menjelma sebagai wasit bagi kemungkinan konflik antar-umat beragama demi terjaganya kerukunan bangsa.

Pada saat bersamaan, negara Pancasila juga meletakkan negara secara otonom di hadapan agama, sehingga agama tidak mengintervensi atau bahkan melakukan religuisasi ideologis atas negara di satu sisi, namun tetap menopang kehidupan bernegara melalui pengembangan etika politik berbasis nilai-nilai agama.

Dalam konteks Islam, hubungan agama yang terpisah pada level kenegaraan namun tetap terhubung secara politik ini menandai beberapa prinsip penting yang khas Indonesia karena keunikan Pancasila. Pertama, terkait dengan penerapan syariat Islam melalui negara. Hal ini tentu telah gugur sejak dihapusnya tujuh kata imbuhan pada sila pertama Pancasila, "dengan kewajiban menjalankan syariat Islam bagi pemeluk-pemeluknya". Pada awalnya, tujuh kata ini merupakan rumusan Pancasila ala Panitia 
Sembilan pada 22 Juni 1945 yang terkenal dengan Piagam Jakarta. Karena khawatir dengan kemungkinan formalisasi syariat oleh negara, kalangan nasionalis dan Kristen mengusulkan penghapusan tujuh kata ini, dan meletakkan prinsip ketuhanan seumum dan universal mungkin, sehingga tidak mewakili kelompok agama tertentu.

Inisiatif Soekarno untuk menjadikan Piagam Jakarta sebagai prinsip yang menjiwai UUD 1945 pada Dekrit Presiden 1959, merupakan cara agar tujuh kata ini menjiwai dasar negara dan konstitusi Indonesia. Tentu hal ini untuk meredam kalangan Islam yang pada Sidang Konstituante ingin menjadikan Islam sebagai dasar negara melalui penghidupan kembali Pancasila ala Piagam Jakarta.

Hanya saja kegagalan Islam sebagai dasar negara Indonesia dan penerapan syariat oleh negara diobati oleh penerapan partikel syariah dalam kerangka pengelolaan waris, nikah, wakaf dan haji yang dilegalkan baik melalui legislasi Kompilasi Hukum Islam, pendirian Peradilan Islam hingga Kementerian Agama. Artinya, meskipun tak menjadi dasar negara, syariah telah dilegalkan serta difalisitasi pelaksanaannya dalam beberapa hal tersebut.

Kedua, terdapat kesadaran di kalangan Muslim moderat untuk tidak menerapkan syariah baik sebagai konstitusi (qanun) maupun UndangUndang (dustur), untuk lebih menegakkannya sebagai etika publik. Pemikiran semacam ini telah digaungkan oleh para pemikir Islam moderat, tidak hanya di Indonesia tetapi dunia. Pemikir Islam asal Sudan, Abdullah Ahmed al-Na'im misalnya, menyepakati wilayah syariah tidak di ranah kenegaraan, melainkan di ruang publik. Sebab pelaksanaan syariah yang merupakan ibadah mengandaikan keihlasan Muslim di hadapan Tuhan. Pelaksanaan melalui regulasi negara akan memberikan beban pemaksaan dari luar diri, sehingga mengurangi dimensi transendennya. Pada titik inilah syariah lebih pas dikembangkan di ruang publik, menjadi dasar bagi nalar publik (public reason) yang digerakkan oleh warga negara demi 
pembangunan politik demokratis. ${ }^{13}$

Dalam konteks ini, al-Naim sebagaimana kalangan moderat di Indonesia menyepakati pemisahan Islam dari negara dengan tetap menjaga hubungan Islam dan politik. Ini dilakukan melalui pembedaan antara negara dan politik. Negara ialah organisasi yang menjadi agen pelaksana cita-cita politik. Sedangkan politik itu sendiri merupakan medan, mekanisme sekaligus tujuan dari pendirian negara. Wilayah negara bersifat terbatas, yakni di lingkungan kelembagaan negara. Sedangkan wilayah politik lebih luas, meliputi seluruh wilayah sosial kehidupan bermasyarakat dan berbangsa. Dalam wilayah politik inilah, warga negara menjadi subjek utama politik untuk mengembangkan nilai-nilai demokratis. Di titik inilah nilai-nilai syariah bisa ditegakkan dalam rangka perwujudan hak asasi manusia dan tata masyarakat berkeadilan.

Peletakan Islam dan syariah sebagai pendorong keadaban politik di ruang publik ini juga menjadi sifat dasar agama-agama di Indonesia. Artinya, ketika agama tidak menjadi agama negara (state religion), ia kemudian memerankan diri sebagai agama publik (public religion). Hal ini disinyalir oleh Benyamin F. Intan dalam Public Religion and the PancasilaBased State of Indonesia. ${ }^{14}$ Menurutnya, agama-agama di Indonesia telah memerankan diri sebagai sumber normatif bagi pembentukan etika politik yang menjadi pemandu bagi gerakan-gerakan keagamaan sipil demokratik. Hal ini sekali lagi berkat Pancasila yang menjadi dasar bagi peran publik agama-agama. Sila pertama yang memuat nilai ketuhanan universal, yang berujung pada sila keadilan sosial, telah mengukuhkan komitmen agamaagama untuk memperjuangkan keadilan berdasarkan nilai-nilai ketuhanan.

\footnotetext{
13 Abdullah Ahmed al-Na'im, Islam and the Secular State, Negotiating the Future of Shari'a (USA: Harvard University Press, 2008), 84.

14 Benyamin F. Intan, Public Religion and the Pancasila-Based State of Indonesia (USA: Boston College, 2004), 68.
} 
Dalam kerangka agama publik ini, pola keagamaan di Indonesia telah menganulir tesis sekularisasi baik sekularisasi sebagai kegagalan agama (secularization as a religous decline), maupun sekularisasi sebagai privatisasi agama (secularization as privatization). Artinya, agama tidak gagal di hadapan sistem pengetahuan dan sosial-politik modern, karena ia masih menjadi paradigma, kultur dan panduan etika politik warga negara Indonesia. Agama juga tidak hanya menjadi urusan privat yang mengabaikan peran sosialnya bagi pembangunan masyarakat berkeadilan. Agama dan negara tetap terhubung secara diferensiatif: agama berada di wilayah kultur, sedangkan negara di ranah struktur kelembagaan politik. Keduanya memang terpisah namun saling menopang, sebagaimana hubungan "toleransi kembar" menurut Alfred Stepan di atas.

Dengan demikian, untuk memahami hubungan Islam dan negara di Indonesia, perlu kiranya mengetahui keberadaan Pancasila sebagai ideologi negara Republik Indonesia. Ideologi ini pada awalnya merupakan hasil konsensus dan oleh karenanya kompromi ideologis dan politis di antara para pendiri bangsa yang secara umum terbagi dalam tiga aliran politik; Islam, nasionalis dan komunis. Dalam perjalanannya, Pancasila menjadi titik temu ideologi-ideologi dunia itu dan menghasilkan rumusan ideologis khas bangsa Indonesia yang menyatukan prinsip ketuhanan di satu sisi, dan kebangsaan modern demokratis pada saat bersamaan. Ini yang membuat corak Islam di Indonesia secara umum bersifat moderat dan nasionalis.

\section{Pancasila dan Deradikalisasi}

Dengan memahami pola hubungan agama, Pancasila, dan NKRI di atas, maka paham radikal Islam yang mendelegitimasi Pancasila gugur secara teoritik, etis dan bahkan keislaman. Hal ini patut dimengerti sebab HTI misalnya masih mempertanyakan Pancasila sebagai dasar negara yang sah secara keagamaan. Dalam Al-Banshasila Falsafah Kufr la Tattafiq Ma'al 
Islam (Pancasila Falsafah Kafir Tidak Sesuai dengan Islam), organisasi berkarakter dasar partai politik ini mengafirkan Pancasila karena dua alasan. Pertama, ia mengakomodir pluralisme agama. Kedua, memuat pluralisme ideologi seperti humanisme, nasionalisme, demokrasi dan sosialisme. Kedua macam pluralisme ini menciderai kebenaran Islam sebagai agama (din) maupun sebagai ideologi (mabda'). Pada saat bersamaan, di samping mengafirkannya, HTI juga beretorika mendasarkan perjuangan penegakan syariahnya pada sila ketuhanan Pancasila, melalui upaya penghidupan kembali tujuh kata, "dengan kewajiban melaksanakan syariat Islam bagi pemeluknya" yang menjadi rumusan Piagam Jakarta. Dengan demikian, perjuangan pendirian khilafah dan penegakan syariah justru merupakan hak bagi mereka berdasarkan sila ketuhanan Pancasila. ${ }^{15}$

Dalam hal ini agar agenda deradikalisasi pemahaman agama yang selama ini menjadi sumbu dari terorisme berjalan efektif, pemerintah tidak hanya menggunakan pendekatan kekuatan keras (hard power), melainkan juga kekuatan lunak (soft power). Dalam hard power, deradikalisasi bersifat represif melalui perundang-undangan, kekuatan militer (TNI dan Polri), serta penegakan hukum atas pelaku terorisme. Pendekatan hard power ini memang penting namun ia seperti pemadam kebakaran yang diberlakukan setelah kebakaran terjadi. Ia belum mampu menghilangkan atau meminimalisir sumber api yang menyebabkan kebakaran tersebut.

Pendekatan soft power yang bersifat preventif, hendak mematikan sumber api terorisme, yakni paham keagamaan radikal. Inilah arti penting deradikalisasi. Sebagaimana diketahui, deradikalisasi memiliki dua makna: pemutusan (disengagement) dan deideologisasi (deideologization). Pemutusan artinya mendorong kalangan radikal untuk mereorientasi diri melalui perubahan sosial-kognitif sehingga mereka meninggalkan norma, nilai,

15 Ainur Rafiq, Membongkar Proyek Khilafah, 65. 
aspirasi dan perilaku yang diikuti sebelumnya, menuju norma baru.

Sedangkan deideologisasi merupakan agenda kontra-ideologi. Artinya menghapus pemahaman ideologis atas agama, sehingga agama tidak lagi dipahami sebagai ideologi politik, melainkan nilai-nilai luhur yang menyemai perdamaian. Dalam kerangka deideologisasi inilah deradikalisasi bisa dipahami sebagai moderasi pemikiran keagamaan. ${ }^{16}$

Strategi deradikalisasi berbasis Pancasila memiliki dua posisi strategis. Pertama, ia secara langsung meruntuhkan kritik terdalam kaum radikal atas Pancasila sebagai dasar negara nasional RI. Hal ini dilakukan melalui penunjukan sifat Islami dari Pancasila dan NKRI.

Tentu kaum radikal yang dimaksud di sini ialah radikalisme politik (salafi haroki) dan radikalisme teroristik (salafi jihadi) yang mencitakan pendirian khilafah atau daulah Islamiyyah. Dengan cita-cita seperti ini, NKRI tentu terposisi sebagai opisisi karena ia merupakan praktik kekufuran akibat adopsi atas sistem politik non-Islam.

Pada titik ini, sebagai dasar negara nasional, Pancasila menjadi penyangga bagi bentuk negara-bangsa (nation-state) yang telah membuyarkan kesatuan wilayah politik Islam (kekhilafahan) yang global. Serta menjadi dasar kosntitusional bagi tegaknya kedaulatan rakyat (demokrasi) yang dianggap menciderai kedaulatan Allah (hakimiyyatullah). Ini tentu berbeda dengan khilafah atau daulah Islamiyyah yang berbasis pada hakimiyyatullah, dan menempatkan syariah sebagai konstitusi negara. Maka Pancasila akhirnya dibenturkan dengan konstitusi syariah, NKRI

\footnotetext{
16 Dalam revisi UU No. 15/2003 tentang Pemberantasan Tindak Pidana Terorisme, akan dimasukkan klausul hukuman atas paham/pemikiran keagamaan yang menolak NKRI. Hal ini dilakukan demi langkah preventif penyebaran paham terorisme. Jika klausul ini disahkan, maka radikalisme agama sebagai ideologi akan dikriminalisasi, sebab pada UU Anti-Terorisme yang ada, radikalisme baru bisa dikenai sanksi hukum jika telah melakukan aksi teror, sedangkan pemikirannya tidak bisa dihukumi. Baca pernyataan Menkopolhukam atas hal ini, Revisi UU Terorisme, Tak Akui NKRI Berujung Bui, www.tempo.co.id (diakses 22 Januari 2016).
} 
dibenturkan dengan daulah Islamiyyah, dan demokrasi dibenturkan dengan kedaulatan Allah. Logika pembenturan Islam dan Pancasila ini tetap mengendap di kepala kaum radikal, sejak HTI, hingga gerakan jihadis penegak syariah seperti MMI, JAT, JAK, MIT, dll.

Proses peruntuhan argumen kontra-Pancasila ini dilakukan melalui pembuktikan dimensi Islami atau agamis dari Pancasila. Artinya, ketika kaum radikal menolak Pancasila atas nama Islam, maka deradikalisasi berbasis Pancasila menunjukkan sebaliknya: dimensi Islami dari Pancasila dan NKRI.

Hal ini bisa dilakukan mengingat paham mainstream keislaman di Indonesia bersifat moderat dan Pancasilais. Bagi paham mainstream ini, Pancasila secara akidah dan syariah bersifat Islami karena beberapa alasan. Pertama, sila Ketuhanan Yang Maha Esa menandai nilai paling fundamental dari Islam, yakni tauhid, sebagaimana ayat 1 surah al-Ihlash: Qul Huwa Allohu Ahad (Katakanlah bahwa Allah itu Esa). Dengan posisi sila tauhid sebagai sila pertama yang mendasari semua sila Pancasila, maka dasar negara ini secara akidah bersifat tauhidi. Kedua, pendasaran ketuhanan menjadikan konstitusi, UU dan kebijakan negara tidak bertentangan dengan syariat Islam. Dengan demikian, Pancasila yang bertauhid itu tidak melarang dan menghalangi umat Islam dan umat beragama lainnya untuk melaksanakan syariah serta aturan agama-agama di Indonesia.

Ketiga, keempat sila di bawah sila ketuhanan selaras dengan tujuantujuan syariah (maqashid al-syari'ah). Tujuan tersebut merujuk pada perlindungan atas lima hak dasar (al-kulliyat al-khamsah) manusia; menjaga hidup (hifdz al-nafs), menjaga agama (hifdz al-din), menjaga akal (hifdz al-'aql), menjaga harta (hifdz al-maal) dan menjaga kehormatan (hifdz al-'irdl). Penjagaan dan perlindungan atas hak dasar manusia ini selaras dengan nilai kemanusiaan, persatuan, kerakyatan dan keadilan sosial. Artinya, ketika ujung sila Pancasila ialah keadilan sosial, hal ini sama dengan tujuan syariah yang merujuk pada kemaslahatan (al-mashlahat), sebagaimana kaidah 
hukum Islam (figh) menyatakan, haistumakanat al-mashlahah fatsamma syar'u Allah wa haistuma kana syar'u Allah fatsamma al-mashlahah (Di mana ada maslahat, di situ ada syariat. Di mana ada syariat, di situ ada maslahat). Kemaslahatan inilah yang dalam bahasa Pancasila disebut keadilan sosial, dan dalam bahasa (filsafat) politik disebut res publica (kebaikan bersama) yang menjadi dasar bagi sistem pemerintahan republik.

Keempat, penunjukan dimensi Islam atas bangunan negara-bangsa NKRI. Artinya, NKRI telah mendapatkan pengesahan keagamaan sebagai bagian dari sistem politik yang Islami. Hal ini dilakukan oleh warga pesantren dan organisasi Islam moderat seperti Nahdlatul Ulama (NU), melalui empat tahap nasionalisme Islam.

(1) Pengesahan wilayah Nusantara (Hindia-Belanda) sebagai dar alIslam (wilayah Islam) pada Muktamar ke-11 NU di Banjarmasin (1936). Alasannya; selain karena kebebasan umat Islam dalam melaksanakan syariah, di wilayah ini juga pernah tegak kekuasaan Islam melalui kerajaan-kerajaan Islam Nusantara. Dengan demikian, ia merupakan wilayah Islam, meskipun diperintah oleh pemerintahan non-Islam. Berdasarkan pengakuan ini, kaum santri membela Indonesia dari serangan Sekutu dalam perang 10 November 1945, yang digerakkan oleh Resolusi Jihad Kiai Hasyim Asy'ari.

(2) Penerimaan Pancasila dan negara-bangsa oleh para pemimpin Islam dalam Sidang PPKI 1945.

(3) Pengesahan Presiden Soekarno dan seluruh Presiden RI sebagai pemimpin darurat yang memiliki kewenangan melaksanakan syariah (waly al-amri al-dlaruri bi al-syaukah). Disebut darurat karena presiden tidak ditunjuk melalui mekanisme pemilihan Sunni (oleh dewan ahlul halli wal 'aqdi), serta bukan seorang Imam al-A'dhom yang memimpin dunia Islam secara global. Namun 
meskipun darurat, Presiden RI memiliki kewenangan melegalkan syariah dalam konteks hukum nikah, waris, wakaf, haji, dll. Pengesahan ini dilakukan pada Munas Alim Ulama di Cipanas, Bogor, 1954.

(4) Kesetiaan terhadap Pancasila sebagai asas bernegara yang tidak menggantikan Islam sebagai akidah, melalui Munas Alim Ulama di Situbondo, 1979. ${ }^{17}$

Dengan berbagai pengesahan ini, NKRI sah secara syar'i, sehingga tidak ada alasan lagi untuk menolaknya atas nama Islam. Segenap argumentasi Islam atas keabsahan Pancasila dan NKRI inilah yang menjadi tahap pertama deradikalisasi Islam berbasis nilai-nilai Pancasila.

Tahap kedua merujuk pada klarifikasi hubungan agama dan negara di dalam negara Pancasila. Ini untuk meluruskan kesalahpahaman kaum radikal yang menilai NKRI sebagai negara sekular yang bertentangan dengan Islam.

Klarifikasi ini dilakukan melalui pembabaran hubungan agama dan negara dalam Pancasila yang tidak bersifat sekular meskipun memang tidak bersifat fundamentalistik. Sebagaimana dijelaskan di atas, Pancasila telah mengembangkan hubungan toleransi kembar (twin toleration), di mana agama menoleransi negara sekaligus mendukungnya, demikian sebaliknya. Dengan cara ini, nilai-nilai agama tidak diusir dari ruang publik dan penyelenggaraan negara, meskipun memang tidak menjadi lembaga negara tersendiri. Pola hubungan toleransi kembar ini tak dipahami kaum radikal, karena mereka hanya memiliki pola pikir oposisional: sekular versus Islami.

Lebih jauh lagi, garis politik Pancasila telah menghadirkan konsep politik yang justru lebih sesuai dengan nilai-nilai politik Islam, jauh berbeda

\footnotetext{
17 Abdurrahman Wahid, Agama, Negara dan Sikap Moderat NU, Pengantar buku, Einar M. Sitompul, NU dan Pancasila (Jakarta: Sinar Harapan, 1989), 3-4.
} 
dengan sistem politik yang dibangun oleh Negara Islam ala radikalisme. Konsep politik ini merujuk pada negara kesejahteraan (welfare state), di mana ujung dari semua proses bernegara ialah keadilan sosial bagi seluruh rakyat. Hal ini senada dengan kaidah fikih, Tasahrruf al-imam 'ala al-ra'iyyah manuthun bi al-mashlahat (Kebijakan pemimpin terkait erat dengan kesejahteraan rakyat). Serta selaras dengan maqashid al-syari'ah dan sifat dasar Islam sebagai agama kasih bagi sekalian alam (rahmatan lil 'alamin).

Dalam konteks ini, tujuan kesejahteraan rakyat melampaui negara dan bentuk negara. Artinya, keberadaannya tidak tergantung dengan bentuk negara tertentu, selama bentuk negara tersebut tidak menciderai prinsip kesejahteraan rakyat. Hal ini terjadi karena kesejahteraan rakyat merupakan hakikat dari politik, yang berusaha diwujudkan oleh lembaga negara. Inilah yang tak terpikirkan oleh kaum radikal: pembedaan negara dan politik, dan penyamaan keduanya secara ontologis. Padahal dengan membedakan keduanya, kita bisa membedakan antara cara dan tujuan. Hal ini yang dilakukan oleh mainstream umat Islam moderat yang memilah antara cara dan tujuan (al-ghayah wa al-wasail). Selama sebuah tujuan bisa dicapai, maka bentuk dari alat tidak lagi penting, selama bentuk tersebut tidak menciderai tujuan yang ada. Hal ini juga bisa diterapkan dalam memahami hubungan Islam dan negara. Selama tujuan politik Islam, yakni kemaslahatan rakyat (al-mashalih al-ra'iyyah) bisa tercapai; bentuk negara tidak lagi penting, apakah ia berbentuk Islam atau negara nasional.

Dengan demikian, Pancasila sebenarnya mendidik warga negara dan umat beragama untuk memperjuangkan hakikat politik. Sebab sebagaimana dijelaskan Ahmed al-Na'im di atas, negara dan politik perlu dibedakan, karena yang pertama merupakan alat, sedang yang terakhir menjadi tujuan. Perjuangan kaum radikal mendirikan Negara Islam adalah pengabaian tujuan berpolitik, karena terfokus pada bentuk (negara). Pertanyaannya, manakah yang harus diperjuangkan? Bentuk negara ataukah fungsi negara? Kaum radikal memperjuangkan bentuk (Islami), sedangkan kaum moderat 
berusaha mendorong negara menjalankan fungsinya, yang termaktub di dalam Pancasila.

Dengan dua tahapan umum deradikalisasi berbasis Pancasila ini, kaum radikal dididik untuk memahami hakikat politik Islam melalui Pancasila. Pada titik ini, deradikalisasi juga bermakna pendidikan kewarganegaraan kepada kaum radikal melalui substansi ajaran Islam yang selaras dengan Pancasila.

\section{Penutup}

Demikianlah. Kaum radikal Islam politik (salafi haroki) sebenarnya mengidap cacat bawaan di dalam nalar politiknya. Yakni pemahaman simbolik atas politik, sehingga yang diperjuangkan ialah bentuk dan simbol negara, bukan fungsi negara dalam konteks hakikat politik sendiri. Memang di dalam tradisi pemikiran politik Islam sendiri, terdapat dua tujuan politik Islam. Pertama, penegakan syariat Islam sebagai fungsi pelanjutan misi Nabi Muhammad SAW. Kedua, penciptaan kemaslahatan (kesejahteraan) rakyat.

Hanya saja terdapat ambivalensi di dalam tujuan pertama, karena ia mensyaratkan bangunan kebangsaan yang murni Islam. Artinya, penerapan syariat melalui Negara Islam hanya bisa dilakukan di dalam masyarakat Muslim sebagaimana negara-negara Timur Tengah. Sedangkan di Indonesia, hal itu tidak bisa ditegakkan, mengingat watak kebangsaan Indonesia yang majemuk secara agama. Oleh karenanya, satu-satunya pilihan yang bermanfaat ialah penegakan tujuan syariat (maqashid al-syari'ah) yang memuat perlindungan atas HAM dan sesuai dengan nilai-nilai Pancasila. Dalam konteks maqashid al-syari'ah inilah, tujuan pertama selaras dengan tujuan kedua, yakni kesejahteraan rakyat. Sedangkan jika tujuan pertama politik Islam ditegakkan melalui ideologi Islamisme radikal, maka penerapan syariat akan bertentangan dengan kesejahteraan rakyat, karena ia mengedepankan paham politik ekslusif yang tidak menjadikan keadilan 
sosial sebagai nilai tertinggi dari praktik dan tata politik.

Dalam konteks ini, deradikalisasi Islam berbasis Pancasila tidak hanya bermanfaat bagi moderasi pemahaman keagamaan, namun juga pendidikan kewarganegaraan. Hal ini yang menandaskan satu fakta bahwa tumbuhnya radikalisme disebabkan oleh absennya pendidikan kewarganegaraan yang tepat bagi umat beragama. Negara terbukti alpa dengan tugas mendidik umat beragama agar menjadi warga negara yang baik, sehingga setiap umat beragama akhirnya membenturkan agama dengan prinsip-prinsip kenegaraan. Pendidikan kewarganegaraan berbasis logika keagamaan inilah yang menjadi substansi dari deradikalisasi berbasis nilai-nilai Pancasila, karena umat beragama, terutama kaum radikal Islam diajak memahami nilai-nilai agama yang sebenarnya mendasari sistem politik dan praktik kenegaraan kita. 